\title{
Effect of Root-Zone Temperature on Growth and Quality of Hydroponically Grown Red Leaf Lettuce (Lactuca sativa L. cv. Red Wave)
}

\author{
Masaru Sakamoto*, Takahiro Suzuki \\ Department of Biological Science, Faculty of Biology Oriented Science and Technology, Kindai University, \\ Wakayama, Japan \\ Email: sakamoto@waka.kindai.ac.jp
}

Received 13 August 2015; accepted 13 September 2015; published 16 September 2015

Copyright (C) 2015 by authors and Scientific Research Publishing Inc.

This work is licensed under the Creative Commons Attribution International License (CC BY). http://creativecommons.org/licenses/by/4.0/

(c) (i) Open Access

\section{Abstract}

Soil temperature influences crop growth and quality under field and greenhouse conditions; however, precise investigation using controlled cultivation systems is largely lacking. We investigated effects of root-zone temperatures on growth and components of hydroponically grown red leaf lettuce (Lactuca sativa $\mathrm{L}$. cv. Red Wave) under a controlled cultivation system at $20^{\circ} \mathrm{C}$. Compared with ambient root-zone temperature exposure, a 7-day low temperature exposure reduced leaf area, stem size, fresh weight, and water content of lettuce. However, root-zone heating treatments produced no significant changes in growth parameters compared with ambient conditions. Leaves under low root-zone temperature contained higher anthocyanin, phenols, sugar, and nitrate concentrations than leaves under other temperatures. Root oxygen consumption declined with low temperature root exposure, but not with root heating. Leaves of plants under low rootzone temperature showed hydrogen peroxide production, accompanied by lipid peroxidation. Therefore, low temperature root treatment is suggested to induce oxidative stress responses in leaves, activating antioxidative secondary metabolic pathways.

\section{Keywords}

Root-Zone Temperature, Anthocyanin, Red Leaf Lettuce, Hydroponics, Drought Stress

\section{Introduction}

Plant growth and development are influenced by various environmental factors, including light, temperature,

\footnotetext{
${ }^{*}$ Corresponding author.
}

How to cite this paper: Sakamoto, M. and Suzuki, T. (2015) Effect of Root-Zone Temperature on Growth and Quality of Hydroponically Grown Red Leaf Lettuce (Lactuca sativa L. cv. Red Wave). American Journal of Plant Sciences, 6, $2350-2360$. http://dx.doi.org/10.4236/ajps.2015.614238 
$\mathrm{CO}_{2}$, water supply, and pathogens [1]-[5]. These often trigger plant abiotic and biotic stress responses, including secondary metabolites production, which plays a key role in stress resistance [6]-[8]. Although higher levels of secondary metabolite generation may promote environmental stress tolerance, additional secondary metabolite production needs the energetic costs of synthetic processes, and these costs result in decreased plant growth and development [9] [10]. Constitutive biotic stress-responding mutant plants showed decreased plant size because of the activation of salicylic acid-mediated plant resistance responses, including antimicrobial secondary metabolites production [5]. Therefore, to increase plant metabolite production by controlling their growth environment, suppressive effects on plant growth caused by environmental stresses must be considered.

Control of environmental factors facilitates increased plant metabolites production associated with human health and preference [11] [12]. In tomatoes, salt stress to the roots improves fruit quality by increasing sugars, organic acids, and amino acids [13] [14]. Mild drought stress triggered by immediate surface irrigation of sweet potato plant with nutrient solutions has recently been shown to increase the $\alpha$-tocopherol content in the tuberous roots [15]. In apples, the coordinated expression of genes associated with secondary metabolite synthesis and subsequent production of anthocyanin have been observed in the fruit skin on exposure to sunlight [16]. In leaf vegetables, as in these plants, secondary metabolites are induced by various environmental factors [12] [17]-[19]. Blue and ultraviolet light irradiation increased the anthocyanin content, accompanied by the activation of anthocyanin biosynthetic genes in leaf lettuce [17]. Drought stress applied to hydroponically grown lettuce roots increased the ascorbic acid, polyphenol, and sugar contents [19].

Air temperature is one of the most important environmental factors controlling plant secondary metabolite production [20]-[22]. In the herb Panax quinquefolius, high temperature stress reduced photosynthesis and plant biomass, and increased root secondary metabolite concentrations [23]. The ascorbic acid content in strawberry fruits increased when plants were grown at low temperature [24], whereas anthocyanin content in these fruits was decreased at high temperature [25]. In leaf vegetables, the air temperature acts as a modulator of several metabolic pathways [26]-[28]. When the minimum growing temperature was reduced by $-5^{\circ} \mathrm{C}$, the sugar and ascorbic acid contents of spinach leaves were increased 5-fold and 3-fold, respectively, compared with those of spinach leaves at minimum temperature of $5^{\circ} \mathrm{C}$ [26]. Low temperature also accelerated anthocyanin and chlorophylls production in red leaf lettuce [28]. Although the phenomenon has not been clearly demonstrated in lettuce, changes in secondary metabolites at low temperature are involved in the gene activation of secondary metabolic pathways in maize [29]. Thus, suitable plant growth temperature regulation could modulate plant secondary metabolites according to human health or preferences.

The development of hydroponic techniques in agriculture has permitted the easy regulation of the root environments with respect to humidity, nutrient solution, and temperature. Similar to air temperature, root-zone temperature influences plant metabolites production in various plants [30]-[33]. In African snake tomato, raising the root-zone temperature increased the contents of phenols, ascorbic acid, and chlorophylls in the leaves [30]. In contrast, decreasing the root-zone temperature of cucumber seedlings promoted soluble sugar production [31]. High and low root-zone temperature altered the synthesis and accumulation of several alkaloids differently in Catharanthus roseus and Nicotiana tabacum [32]. In leaf vegetables, temperature stress application to the root-zone shifted the production of some secondary metabolites in the greenhouse [34]-[36]. However, the effect of low temperature stress on lettuce roots grown in controlled cultivation systems is largely unclear. In the present study, using fluorescent lamps as a photosynthetic light source and a DFT hydroponic system, we investigated the effect of root-zone temperature on the growth and components of red leaf lettuce. Furthermore, we measured the hydrogen peroxide production in leaves and discussed the association between low root-zone temperature-induced response and oxidative stress.

\section{Materials and Methods}

\subsection{Plant Material and Growth Condition}

Red leaf lettuce seeds (Lactuca sativa L. cv. Red Wave; Sakata Seed Co., Japan) were pregerminated for 1 day at $20^{\circ} \mathrm{C}$ under $200 \mu \mathrm{mol} \cdot \mathrm{m}^{-2} \cdot \mathrm{s}^{-1}$ photosynthetic photon flux (PPF) for $16 \mathrm{~h}$ using fluorescent lamps (FL40SBRA; NEC Co., Japan). Germinated seeds were sown in sponge cubes $2 \times 2 \times 2 \mathrm{~cm}$ in size and grown under the same conditions. The nutrient solution was based on a half-strength culture solution of the Otsuka House A-recipe (Otsuka Chemical Co. Ltd., Japan), as described previously [37]. At 16 days after sowing (DAS), seedlings were transferred to the DFT hydroponic system with continuous aeration under $250 \mu \mathrm{mol} \cdot \mathrm{m}^{-2} \cdot \mathrm{s}^{-1} \mathrm{PPF}$ 
to acclimate to the hydroponic system. At 22 DAS, root-zone temperature treatments were initiated under the same light condition. Root-zone heating $\left(25^{\circ} \mathrm{C}\right.$ and $\left.30^{\circ} \mathrm{C}\right)$ was applied with an IC auto heater (DS 150; DEX Co. Ltd., Japan). Low root-zone temperature $\left(10^{\circ} \mathrm{C}\right)$ was maintained by cooling the nutrient solution using a cool water circulator (Coolman pal C-307, Shibata Co. Ltd., Japan). After 7 days of root temperature treatment (29 DAS), plants were harvested and the growth parameters and components were analyzed. Specific leaf area (SLA) was calculated as the plant leaf area divided by the leaf dry weight.

\subsection{Measurement of Total Phenol Content}

The total phenol content was measured using the modified Folin-Ciocalteu method described previously [38], with slight modifications. Leaf segments (50 mg) were homogenized with $500 \mu \mathrm{L}$ of $90 \%$ methanol and stored at $4^{\circ} \mathrm{C}$ overnight. The sample was then centrifuged at $10,000 \mathrm{~g}$ for $5 \mathrm{~min}$ at room temperature. The supernatant $(50 \mu \mathrm{L})$ was diluted with distilled water to $650 \mu \mathrm{L}$, and $50 \mu \mathrm{L}$ phenol reagent was mixed with it. After adding $300 \mu \mathrm{L}$ of $5 \%$ sodium carbonate, the mixture was incubated at $25^{\circ} \mathrm{C}$ for $30 \mathrm{~min}$. The absorbance of the supernatant was measured at $765 \mathrm{~nm}$, and a standard curve was prepared using gallic acid. The absorbance was converted to the total phenol content in terms of milligrams of gallic acid equivalent per gram of fresh weight of sample.

\subsection{Measurement of Anthocyanin Content}

The anthocyanin content was spectrophotometrically measured as described previously [38], with slight modifications. Leaf segments (50 mg) were homogenized with $1 \mathrm{~mL}$ methanol containing $1 \%$ hydrochloric acid and stored at $4^{\circ} \mathrm{C}$ overnight. The sample was then centrifuged at $10,000 \mathrm{~g}$ for $5 \mathrm{~min}$ at room temperature. The absorbance of the supernatant was measured at $533 \mathrm{~nm}$, and a standard curve was prepared using cyanidin-3-glucoside. The absorbance was converted to the total phenol content in terms of milligrams of cyanidin-3-glucoside equivalent per gram of fresh weight of sample.

\subsection{Measurement of Ascorbic Acid (AsA) Content}

AsA content was measured as described previously [39], with slight modifications. Leaf segments (1 g) were homogenized with $10 \mathrm{~mL} 5 \%(\mathrm{w} / \mathrm{v})$ metaphosphoricacid. The sample was then centrifuged at $6000 \mathrm{~g}$ for $5 \mathrm{~min}$ at room temperature. AsA was measured in the supernatant with a reflectometer (RQflex plus, Merck, Germany) and analysis strips (Ascorbic Acid Test, Merck).

\subsection{Measurement of Soluble Solid Content}

Leaf segments were homogenized with mortar and pestle, and the homogenates were filtered with a filter paper (No. 1, Whatman plc., UK) to remove tissue debris. The soluble solids content was measured as Brix degree using an Atago PAL-1 Handheld Digital Brix Refractometer (Atago, Japan).

\subsection{Measurement of Nitrate Content}

Leaf segments (50 mg) were homogenized with $1 \mathrm{~mL}$ deionized water. The homogenate was filtered through a filter paper to remove tissue debris. The nitrate content was measured with a reflectometer (RQflex plus) and analysis strips (Nitrate Test, Merck).

\subsection{Measurement of Root Activity}

Fresh roots $(50 \mathrm{mg}$ ) were washed with distilled water and submersed in a $50 \mathrm{~mL}$ tube with oxygen-saturated nutrient solution for $1 \mathrm{~h}$. The initial and final dissolved oxygen concentrations were measured using dissolved oxygen meter DO-5509 (Lutron, Taiwan), for calculation of the depleted dissolved oxygen.

\subsection{Measurement of Oxidative Stress}

A leaf disc after 7 days of root-zone temperature treatment was treated with $1 \mathrm{mg} \cdot \mathrm{mL}^{-1} 3,3^{\prime}$-diaminobenzidine (DAB) solution and incubated for $5 \mathrm{~h}$. The treated leaf disc was boiled in $90 \%$ ethanol at $95^{\circ} \mathrm{C}$ for $3 \mathrm{~min}$ and then observed under a light microscope. The radical scavenging activity was measured using 1,1-diphenyl-2- 
picrylhydrazyl (DPPH) radicals and expressed as the percentage of DPPH radical neutralization after 30-min incubation as previously described [38]. The level of malondialdehyde (MDA, a lipid peroxidation product) was determined by thiobarbituric acid reaction (TBAR) method [40], with slight modification. A fresh leaf segments (100 mg) were homogenized in $0.5 \mathrm{~mL}$ of $0.1 \%$ trichloroacetic acid (TCA) solution. The homogenate was centrifuged at $10,000 \mathrm{~g}$ for $5 \mathrm{~min}$, and $0.2 \mathrm{~mL}$ of the supernatant was added to $0.8 \mathrm{~mL}$ of $0.5 \%$ TBA in $20 \%$ TCA. The mixture was incubated at $95^{\circ} \mathrm{C}$ for $30 \mathrm{~min}$ and then the reaction was stopped by cooling on ice. After centrifugation at 10,000 $\mathrm{g}$ for $5 \mathrm{~min}$ at room temperature, the absorbance of the supernatant was measured at 532 $\mathrm{nm}$ and the nonspecific absorbance at $600 \mathrm{~nm}$ was subtracted. The concentration of MDA was quantified using a molar extinction coefficient of $155 \mathrm{mM}^{-1} \cdot \mathrm{cm}^{-1}$.

\subsection{Data Analysis}

The data obtained for each parameter were analyzed with the statistical package JMP (SAS Institute, Cary, NC, USA). Differences among treatments were determined by one-way analysis of variance (ANOVA). Mean comparisons were made using the Tukey-Kramer honestly significant difference multiple range test at $p<0.05$.

\section{Results}

\subsection{Plant Growth}

Red leaf lettuce plants at 22 DAS were treated with 4 different root-zone temperatures $\left(10^{\circ} \mathrm{C}, 20^{\circ} \mathrm{C}, 25^{\circ} \mathrm{C}\right.$, and $30^{\circ} \mathrm{C}$ ) at $20^{\circ} \mathrm{C}$ air temperature. After 7 days of treatment, the shoot size was reduced in plants in the low rootzone temperature treatment $\left(10^{\circ} \mathrm{C}\right)$ group from that of the plants in the $20^{\circ} \mathrm{C}$ ambient root-zone temperature (Figure 1). In contrast, root-zone heating treatments $\left(25^{\circ} \mathrm{C}\right.$ and $\left.30^{\circ} \mathrm{C}\right)$ led to no obvious morphological changes (Figure 1). In the growth parameter analysis, the leaf area was decreased by root-zone cooling from that of the plants at other temperature treatments, whereas no significant difference was observed in leaf number (Table 1). Similarly to leaf area, the stem diameter was smaller in plants under low root-zone temperature treatment than that in the plants under other treatments (Table 1). Stem length was increased by root-zone heating, especially at $25^{\circ} \mathrm{C}$, and was not influenced by root-zone cooling (Table 1 ). Top and root fresh weights were reduced by low root-zone temperature treatment from those of the plants with ambient conditions (Table 2). Although no statistically significant difference was observed between different root-zone temperature treatments, the top and root dry weights under low root-zone temperature treatment tended to be lower than those of the plants under ambient root-zone temperature treatment (Table 2). Water contents of the top and root were significantly decreased in plants exposed to low root-zone temperature (Table 2). SLA was significantly lower under $10^{\circ} \mathrm{C}$ than that under $20^{\circ} \mathrm{C}$ treatment (Table 2), indicating that low root-zone temperature led to leaf thickening.

\subsection{Nutrient Content}

Root-zone cooling at $10^{\circ} \mathrm{C}$ promoted red pigmentation of the leaves (Figure 1), suggesting anthocyanin accumulation. In accord with this observation, the anthocyanin and total phenol contents in the leaves were approximately 2-fold greater in the plants under low root-zone temperature treatment than those in plants under other temperature treatments (Figure 2(a) and Figure 2(b)). The leaf ascorbic acid content was slightly increased by root exposure to low temperature, but this difference was not statistically significant (Figure 2(c)). Leaf and root sugar contents, measured by the soluble solid content expressed as Brix degree, were elevated by the root-zone cooling treatment (Figure 3). Heating the root-zone to $30^{\circ} \mathrm{C}$ led to no obvious changes in leaf Brix, but significantly increased root Brix from that of the plants with ambient conditions (Figure 3). With respect to nitrate

Table 1. Growth parameters of red leaf lettuce grown at four different root zone temperatures.

\begin{tabular}{ccccc}
\hline Root-zone temp. & No. of leaves & Leaf area $\left(\mathrm{cm}^{3}\right)$ & Stem length $(\mathrm{cm})$ & Stem diameter $(\mathrm{mm})$ \\
\hline $\mathbf{1 0}^{\circ} \mathbf{C}$ & $6.8 \pm 0.2 \mathrm{a}$ & $103.3 \pm 5.6 \mathrm{~b}$ & $5.3 \pm 0.3 \mathrm{~b}$ & $3.7 \pm 0.1 \mathrm{~b}$ \\
$\mathbf{2 0}^{\circ} \mathbf{C}$ & $7.3 \pm 0.2 \mathrm{a}$ & $140.5 \pm 8.5 \mathrm{a}$ & $5.2 \pm 0.3 \mathrm{~b}$ & $4.7 \pm 0.2 \mathrm{a}$ \\
$\mathbf{2 5}^{\circ} \mathbf{C}$ & $7.2 \pm 0.2 \mathrm{a}$ & $134.0 \pm 5.8 \mathrm{ab}$ & $6.3 \pm 0.1 \mathrm{a}$ & $4.8 \pm 0.2 \mathrm{a}$ \\
$\mathbf{3 0}^{\circ} \mathbf{C}$ & $7.6 \pm 0.2 \mathrm{a}$ & $131.1 \pm 4.5 \mathrm{ab}$ & $6.1 \pm 0.1 \mathrm{ab}$ & $4.6 \pm 0.1 \mathrm{a}$ \\
\hline
\end{tabular}

Values are mean \pm SE $(n=6)$. Different letters in the same column indicate significant differences by Tukey's multiple comparison test $(p<0.05)$. 
Table 2. Fresh weight, dry weight, water content and SLA of red leaf lettuce grown at four different root zone temperatures.

\begin{tabular}{cccccccc}
\hline $\begin{array}{c}\text { Root-zone } \\
\text { temp. }\end{array}$ & $\begin{array}{c}\text { Top fresh } \\
\text { weight (g) }\end{array}$ & $\begin{array}{c}\text { Root fresh } \\
\text { weight (g) }\end{array}$ & $\begin{array}{c}\text { Top dry } \\
\text { weight (mg) }\end{array}$ & $\begin{array}{c}\text { Root dry } \\
\text { weight (mg) }\end{array}$ & $\begin{array}{c}\text { Top water } \\
\text { content (\%) }\end{array}$ & $\begin{array}{c}\text { Root water } \\
\text { content (\%) }\end{array}$ & SLA \\
\hline $\mathbf{1 0}^{\circ} \mathbf{C}$ & $3.12 \pm 0.20 \mathrm{~b}$ & $0.61 \pm 0.04 \mathrm{~b}$ & $211 \pm 9 \mathrm{a}$ & $36 \pm 2 \mathrm{a}$ & $93.2 \pm 0.1 \mathrm{~b}$ & $93.2 \pm 0.2 \mathrm{~b}$ & $0.51 \pm 0.02 \mathrm{~b}$ \\
$\mathbf{2 0}^{\circ} \mathbf{C}$ & $4.60 \pm 0.28 \mathrm{a}$ & $0.98 \pm 0.14 \mathrm{a}$ & $253 \pm 12 \mathrm{a}$ & $44 \pm 6 \mathrm{a}$ & $94.5 \pm 0.1 \mathrm{a}$ & $95.5 \pm 0.1 \mathrm{a}$ & $0.57 \pm 0.02 \mathrm{a}$ \\
$\mathbf{2 5}^{\circ} \mathbf{C}$ & $4.51 \pm 0.42 \mathrm{a}$ & $0.82 \pm 0.07 \mathrm{ab}$ & $251 \pm 20 \mathrm{a}$ & $38 \pm 3 \mathrm{a}$ & $94.4 \pm 0.1 \mathrm{a}$ & $95.3 \pm 0.1 \mathrm{a}$ & $0.54 \pm 0.01 \mathrm{ab}$ \\
$\mathbf{3 0}^{\circ} \mathbf{C}$ & $4.11 \pm 0.35 \mathrm{ab}$ & $0.75 \pm 0.11 \mathrm{ab}$ & $233 \pm 19 \mathrm{a}$ & $35 \pm 6 \mathrm{a}$ & $94.3 \pm 0.1 \mathrm{a}$ & $95.4 \pm 0.1 \mathrm{a}$ & $0.56 \pm 0.02 \mathrm{ab}$ \\
\hline
\end{tabular}

Values are mean \pm SE $(n=6)$. Different letters in the same column indicate significant differences by Tukey's multiple comparison test $(p<0.05)$.

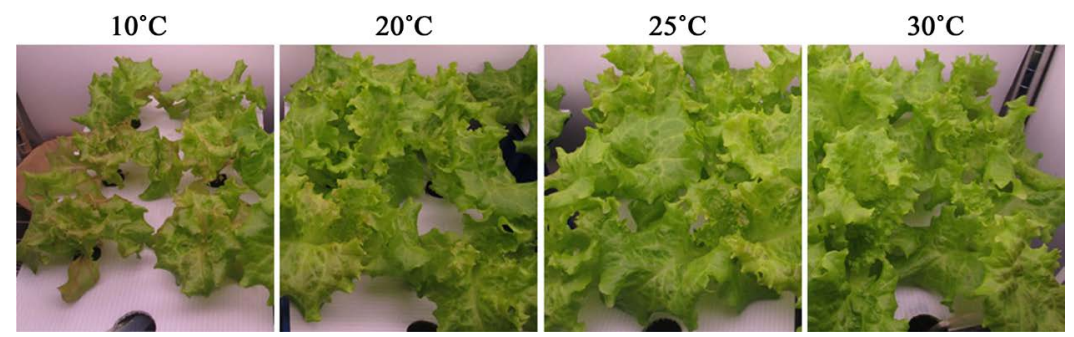

Figure 1. Effect of root-zone temperature on the morphology of red leaf lettuce.

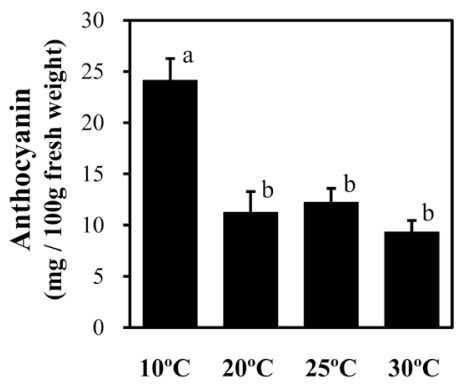

(a)

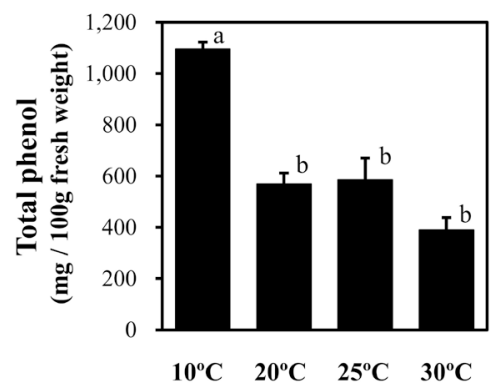

(b)

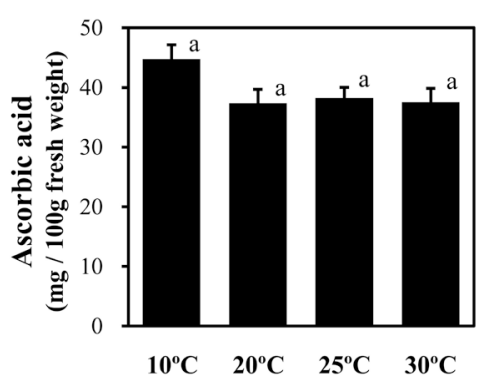

(c)

Figure 2. Effect of root-zone temperature on the anthocyanin, total phenolic, and ascorbic acid contents in red leaf lettuce leaves. Vertical bars represent \pm SE $(n=6)$. Different letters indicate significant differences by Tukey’s multiple comparison test $(p<0.05)$.

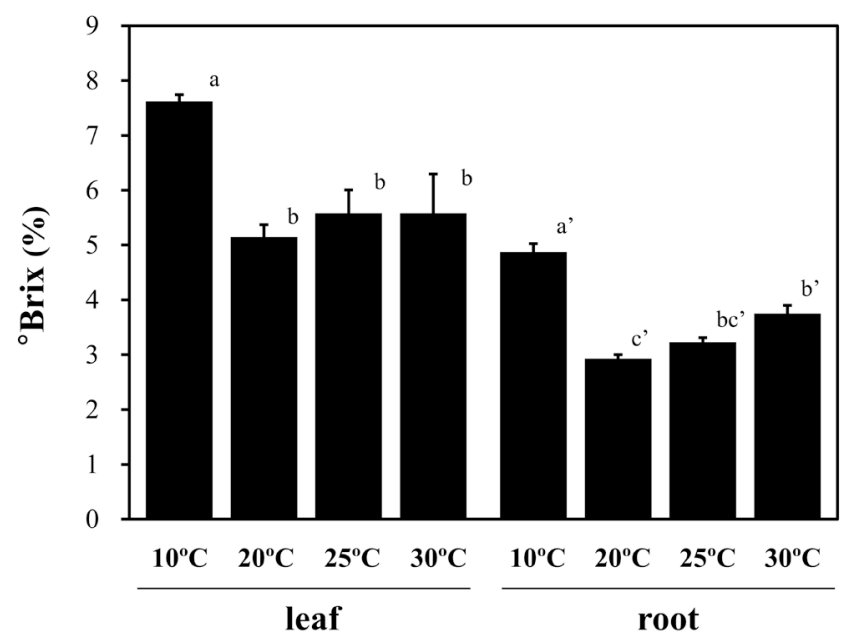

Figure 3. Effect of root-zone temperature on the soluble solids content expressed as Brix degree in red leaf lettuce. Vertical bars represent \pm SE (leaf; $n=6$, root; $n=4)$. Significant differences were detected by Tukey's multiple comparison test $(p<$ 0.05). Statistical analyses were performed separately for the leaf and root, and results are shown by lower-case letters without and with single apostrophes, respectively. 
accumulation, the leaf nitrate content under cool root-zone temperature was less than half of that of the plants under ambient conditions (Figure 4). In contrast, the root nitrate content was not influenced by low root-zone temperature (Figure 4). High root-zone temperature treatments did not affect nitrate concentrations in leaves and roots (Figure 4).

\subsection{Oxidative Stress}

Several stresses to the root-zone alter root respiration [41]-[43]. To monitor the stress response induced by different root-zone temperature treatments, root respiration represented by the root oxygen consumption was measured. The root oxygen consumption was significantly decreased by $40 \%$ in plants under low root-zone temperature treatment from that in the plants with ambient temperature treatment, whereas root-zone heating treatments led to no significant changes (Figure 5). Anthocyanins act as antioxidative compounds protecting plant cells from reactive oxygen species (ROS) [44]. Because low root-zone temperature treatment induced the production of anthocyanin in leaves (Figure 2(a)), we assessed leaf oxidative stress by monitoring the hydrogen peroxide content using DAB. The levels of leaf hydrogen peroxide were increased by low root-zone temperature

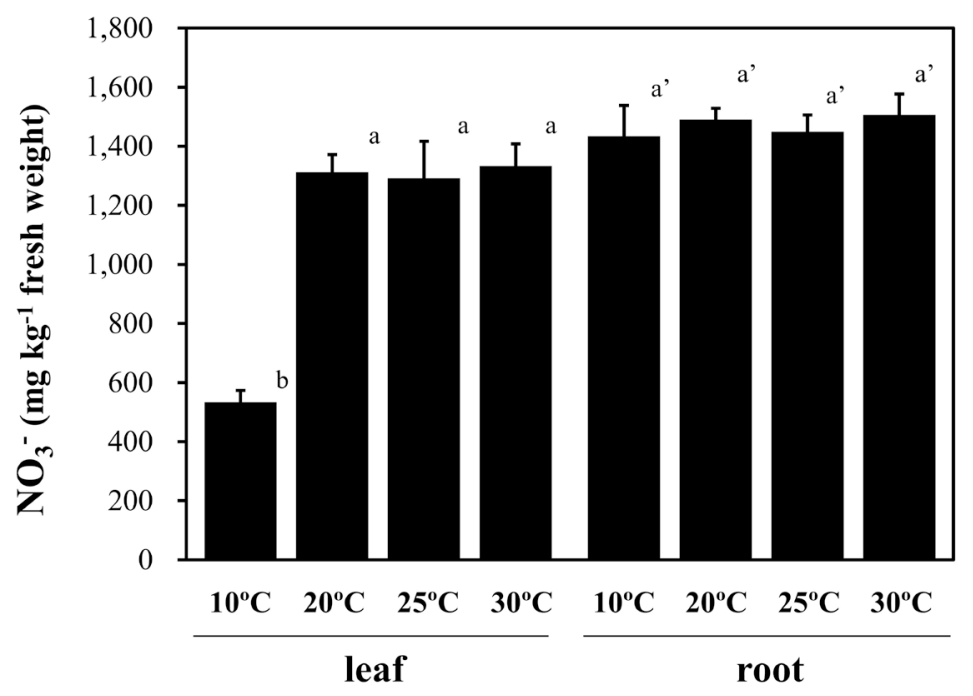

Figure 4. Effect of root-zone temperature on the nitrate content in red leaf lettuce. Vertical bars represent \pm SE (leaf; $n=6$, root; $n=4)$. Significant differences were detected by Tukey's multiple comparison test $(p<0.05)$. Statistical analyses were performed separately for the leaf and root, and results are shown by lower-case letters without and with single apostrophes, respectively.

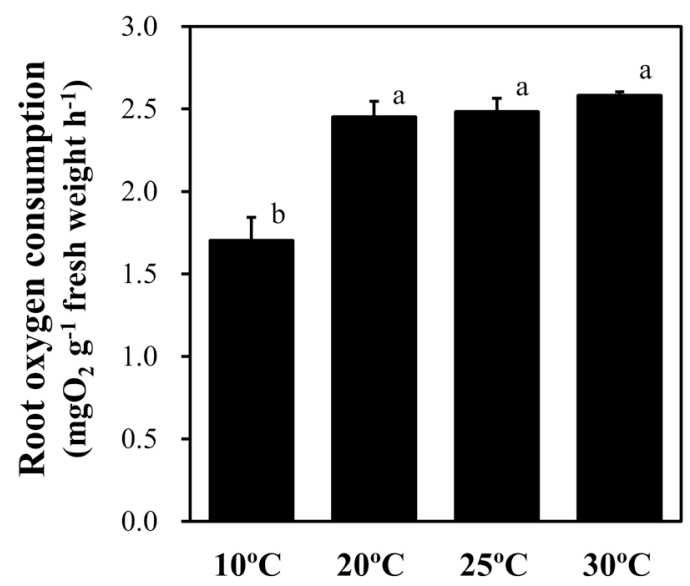

Figure 5. Effect of root-zone temperature on root oxygen consumption of red leaf lettuce leaves. Vertical bars represent \pm SE $(n=6)$. Different letters indicate significant differences by Tukey’s multiple comparison test $(p<0.05)$. 
treatment, as shown by strong DAB signals in leaf cells, especially surrounding vascular tissues (Figure 6), suggesting the presence of oxidative stress in leaves. To assess this stress, ROS scavenging activities were measured as DPPH radical scavenging capacity. This capacity was significantly increased under $10^{\circ} \mathrm{C}$ root-zone treatment from that of plants with ambient temperature treatment (Figure 7). In support of these results, the lipid peroxidation in leaves, measured by the level of MDA content, was strongly increased by root exposure to low temperature (Figure 8).

\section{Discussion}

Although suboptimal root-zone temperature tends to restrict plant growth, responsiveness to root-zone temperature depends on the plant species [45]. For instance, six Cucurbitaceae species exhibited different responses in the form of changes of biomass, photosynthesis, and stomatal conductance at root-zone temperatures between $14^{\circ} \mathrm{C}$ and $34^{\circ} \mathrm{C}$ [45]. In leaf vegetables, baby leaf plants of greenhouse-grown Valerianella locusta treated with high $\left(25^{\circ} \mathrm{C}\right)$ or low $\left(15^{\circ} \mathrm{C}\right)$ root-zone temperature displayed smaller plant size than that of plants treated with a

$10^{\circ} \mathrm{C}$
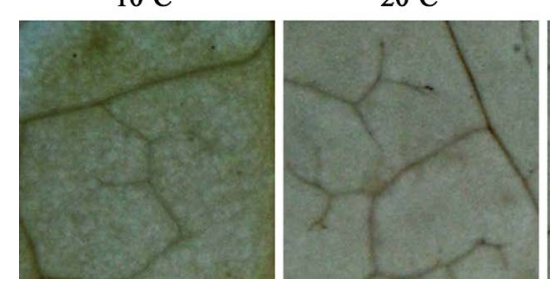

$25^{\circ} \mathrm{C}$

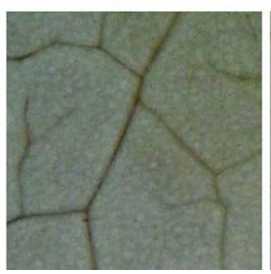

$30^{\circ} \mathrm{C}$

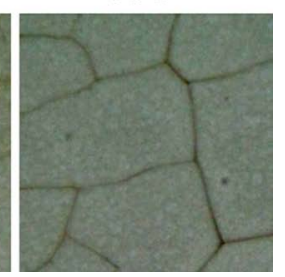

Figure 6. Effect of root-zone temperature on hydrogen peroxide production in red leaf lettuce leaves.

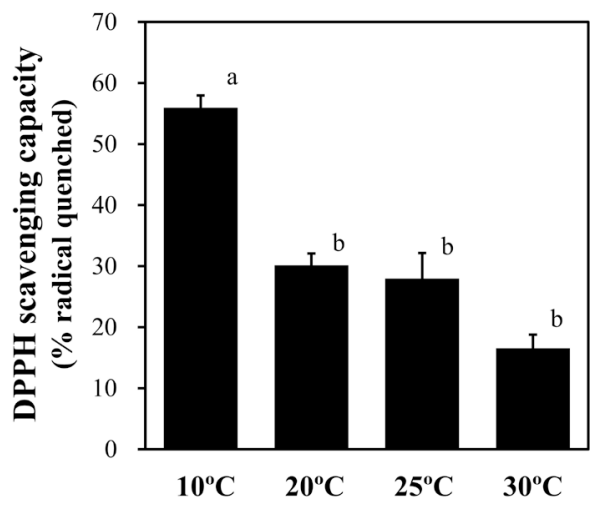

Figure 7. Effect of root-zone temperature on the DPPH radical scavenging capacity of red leaf lettuce leaves. Vertical bars represent \pm SE $(n=6)$. Different letters indicate significant differences by Tukey’s multiple comparison test $(p<0.05)$.

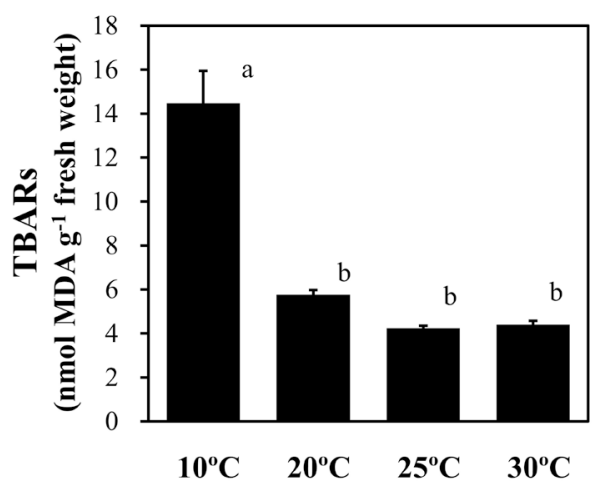

Figure 8. Effect of root-zone temperature on lipid peroxidation in baby leaf lettuce leaves. Vertical bars represent \pm SE $(n=$ 6). Different letters indicate significant differences by Tukey's multiple comparison test $(p<0.05)$. 
middle temperature $\left(20^{\circ} \mathrm{C}\right)[36]$. In the present study we showed that exposure of red leaf lettuce roots to low temperature significantly reduced leaf area, stem diameter, and fresh weight of tops and roots (Table 2). These findings suggest that low temperature treatment of roots triggers stress responses in the whole plant, resulting in the reduction of leaf and root growth. Our experiment showed that root-zone heating led to no significant changes of plant biomass (Table 2). In contrast to our results, root-zone cooling at $20^{\circ} \mathrm{C}$ increased the biomass of aeroponically grown lettuce from that in plants with ambient conditions $\left(24^{\circ} \mathrm{C}-38^{\circ} \mathrm{C}\right)$ in a tropical greenhouse [46]. Because these experimental air and ambient root-zone temperatures were presumably higher than ours, root-zone cooling at $20^{\circ} \mathrm{C}$ in that report may have optimized plant growth rather than triggering low-temperature stress responses.

The production of various plant metabolites is influenced by root-zone temperature in many plants, including leaf vegetables [30]-[34] [46]-[49]. Our results showed that human-preferred compounds such as anthocyanin, phenols, and sugar were significantly increased in red leaf lettuce leaves when their roots were exposed to low temperature (Figure 2 and Figure 3). In support of our results, sugar accumulation has been observed in spinach, cotton, and tomato upon exposure of the roots to low temperature [34] [48] [49]. In contrast, we showed that exposure of roots to high temperature did not alter the contents of anthocyanin, phenols, and sugars in the leaves (Figure 2 and Figure 3). However, raising soil temperature with electric heating cables suppressed the accumulation of lettuce anthocyanin and sugar in a previous field experiment [47]. Because root oxygen consumption was not influenced by root exposure to high temperature (Figure 5), the heating temperature range $\left(25^{\circ} \mathrm{C}\right.$ and $30^{\circ} \mathrm{C}$ ) in our experiment may not have been sufficient to cause a stress response, leading to growth reduction. Interestingly, while the sugar content was altered in the leaves and roots by low root-zone temperature treatment (Figure 3), the nitrate concentration was significantly changed only in the leaves, where it decreased to $40 \%$ of that in plants under ambient conditions (Figure 4). Given that the photosynthetic consumption of nitrate is probably not increased in the leaves by low root temperature stress, suppression of the root nitrate transport to leaves may be the cause of the decreased leaf nitrate concentration.

Root stress, such as drought and salinity, induce the restriction of plant growth, followed by impairment of the leaf photosynthetic capacity [4]. Plant growth inhibition and reduction in photosynthesis have been observed when plants were subjected to low root temperature in some plants [50]-[52]. Subjection of roots to low temperature caused a decline of water uptake, leading to an inhibition of photosynthesis in the shoot growing zones [53]. In Arabidopsis, overexpression of a plasma membrane water channel protein alleviated low root-zone temperature-induced decline of hydraulic activity and plant growth, implicating the role of water uptake in root temperature stress [52]. We observed drought stress-like reduction of the top and root water contents following root exposure to low temperature (Table 2). Because drought stress triggers various secondary metabolic pathways, the leaf production of anthocyanin, phenols, and sugar in our experiment may be a result of the activation of drought stress response (Figure 2 and Figure 3). Indeed, drought stress applied to the roots induced the accumulation of phenols and sugar in hydroponically grown lettuce seedlings [19].

Environmental stress-induced photosynthetic impairment often accompanies oxidative stress [54]. Plants subjected to drought, salinity, and low temperature cause oxidative stress, followed by the reduction of the photosynthetic capacity of the oxygen-evolving complex and associated cofactors in photosystem II (PSII), resulting in limitation of the plant biomass [54] [55]. Salinity stress triggers oxidative stress in leaves, such as the production of ROS, activation of antioxidative enzymes, and leaf chlorosis [42]. Our study revealed that low temperature treatment of lettuce roots induced the accumulation of hydrogen peroxide in the leaves (Figure 6), accompanied by lipid peroxidation (Figure 8). This finding indicated that low temperature stress to the root-zone triggered oxidative stress in leaves, presumably by restricting photosynthesis. Plants cope with oxidative stresses by producing antioxidative metabolites including phenolic compounds like anthocyanin [44] [56]. Our results showed that the leaf anthocyanin and phenol contents are increased by root exposure to low temperature (Figure 2), suggesting the antioxidative roles of these metabolites in response to increased leaf hydrogen peroxide (Figure 6). Moreover, the radical scavenging capacity represented by DPPH was increased in leaves (Figure 7), suggesting the activation of ROS scavenging machinery. Indeed, lettuce exposed to low air temperature showed elevated production of anthocyanin and polyphenols and increased DPPH radical scavenging capacity [57]. The Arabidopsis MYB transcription factor AtMYB60 functions as a transcriptional repressor of anthocyanin biosynthetic genes in lettuce [58]. Given that MYB family proteins are common regulators of the anthocyanin synthetic pathway in many plants [59], low root-zone temperature-induced anthocyanin accumulation in the lettuce leaves is also regulated by intrinsic MYB transcriptional factors. To increase the productivity of human-preferred plant 
secondary metabolites, regulation of these transcription factor(s) may be important for the production of crops with added quality.

\section{References}

[1] Fankhauser, C. and Chory, J. (1997) Light Control of Plant Development. Annual Review of Cell and Developmental Biology, 13, 203-229. http://dx.doi.org/10.1146/annurev.cellbio.13.1.203

[2] Porter, J.R. and Gawith, M. (1997) Temperatures and the Growth and Development of Wheat: A Review. European Journal of Agronomy, 10, 23-36. http://dx.doi.org/10.1016/S1161-0301(98)00047-1

[3] Makino, A. and Mae, T. (1999) Photosynthesis and Plant Growth at Elevated Levels of $\mathrm{CO}_{2}$. Plant \& Cell Physiology, 40, 999-1006. http://dx.doi.org/10.1093/oxfordjournals.pcp.a029493

[4] Chaves, M.M., Flexas, J. and Pinheiro, C. (2009) Photosynthesis under Drought and Salt Stress: Regulation Mechanisms from Whole Plant to Cell. Annuals of Botany, 103, 551-560. http://dx.doi.org/10.1093/aob/mcn125

[5] Rivas-San Vicente, M. and Plasencia, J. (2011) Salicylic Acid beyond Defence: Its Role in Plant Growth and Development. Journal of Experimental Botany, 62, 3321-3338. http://dx.doi.org/10.1093/jxb/err031

[6] Zhao, J., Davis, L.C. and Verpoorte, R. (2005) Elicitor Signal Transduction Leading to Production of Plant Secondary Metabolites. Biotechnology Advances, 23, 283-333. http://dx.doi.org/10.1016/j.biotechadv.2005.01.003

[7] Namdeo, A.G. (2007) Plant Cell Elicitation for Production of Secondary Metabolites: A Review. Pharmacognosy Reviews, 1, 69-79.

[8] Akula, R. and Ravishankar, G.A. (2011) Influence of Abiotic Stress Signals on Secondary Metabolites in Plants. Plant Signaling \& Behavior, 6, 1720-1731. http://dx.doi.org/10.4161/psb.6.11.17613

[9] Hofmann, R.W. and Jahufer, M.Z. (2011) Tradeoff between Biomass and Flavonoid Accumulation in White Clover Reflects Contrasting Plant Strategies. PLoS One, 6, e18949. http://dx.doi.org/10.1371/journal.pone.0018949

[10] Huot, B., Yao, J., Montgomery, B.L. and He, S.Y. (2014) Growth-Defense Tradeoffs in Plants: A Balancing Act to Optimize Fitness. Molecular Plant, 7, 1267-1287. http://dx.doi.org/10.1093/mp/ssu049

[11] Bourgaud, F., Gravot, A., Milesi, S. and Gontier, E. (2001) Production of Plant Secondary Metabolites: A Historical Perspective. Plant Science, 161, 839-851. http://dx.doi.org/10.1016/S0168-9452(01)00490-3

[12] Oh, M.M., Carey, E.E. and Rajashekar, C.B. (2009) Environmental Stresses Induce Health-Promoting Phytochemicals in Lettuce. Plant Physiology and Biochemistry, 47, 578-583. http://dx.doi.org/10.1016/j.plaphy.2009.02.008

[13] Adams, P. (1991) Effects of Increasing the Salinity of the Nutrient Solution with Major Nutrients or Sodium Chloride on the Yield, Quality and Composition of Tomatoes Grown in Rockwool. Journal of Horticultural Science, 66, 201207.

[14] Gao, Z., Sagi, M. and Lips, S.H. (1998) Carbohydrate Metabolism in Leaves and Assimilate Partitioning in Fruits of Tomato (Lycopersicon esculentum L.) as Affected by Salinity. Plant Science, 135, 149-159. http://dx.doi.org/10.1016/S0168-9452(98)00085-5

[15] Eguchi, T., Ito, Y. and Yoshida, S. (2015) Instantaneous Flooding and $\alpha$-Tocopherol Content in Tuberous Roots of Sweet Potato (Ipomoea batatas (L.) Lam.). Environmental Control in Biology, 53, 13-16. http://dx.doi.org/10.2525/ecb.53.13

[16] Takos, A.M., Jaffé, F.W., Jacob, S.R., Bogs, J., Robinson, S.P. and Walker, A.R. (2006) Light-Induced Expression of a MYB Gene Regulates Anthocyanin Biosynthesis in Red Apples. Plant Physiology, 142, 1216-1232. http://dx.doi.org/10.1104/pp.106.088104

[17] Johkan, M., Shoji, K., Goto, F., Hahida, S. and Yoshihara, T. (2011) Effect of Green Light Wavelength and Intensity on Photomorphogenesis and Photosynthesis in Lactuca sativa. Environmental and Experimental Botany, 75, 128-133. http://dx.doi.org/10.1016/j.envexpbot.2011.08.010

[18] Liu, W.K. and Yang, Q.C. (2011) Effects of Short-Term Treatment with Various Light Intensities and Hydroponic Solutions on Nitrate Concentration of Lettuce. Acta Agriculturae Scandinavica Section B—Soil \& Plant Science, 62, 109113. http://dx.doi.org/10.1080/09064710.2011.580366

[19] Koyama, R., Itoh, H., Kimura, S., Morioka, A. and Uno, Y. (2012) Augmentation of Antioxidant Constituents by Drought Stress to Roots in Leafy Vegetables. HortTechnology, 22, 121-125.

[20] Kaplan, F., Kopka, J., Haskell, D.W., Zhao, W., Schiller, K.C., Gatzke, N., Sung, D.Y. and Guy, C.L. (2004) Exploring the Temperature-Stress Metabolome of Arabidopsis. Plant Physiology, 136, 4159-4168. http://dx.doi.org/10.1104/pp.104.052142

[21] Zobayed, S.M.A., Afreen, F. and Kozai, T. (2005) Temperature Stress Can Alter the Photosynthetic Efficiency and Secondary Metabolite Concentrations in St. John's Wort. Plant Physiology and Biochemistry, 43, 977-984. http://dx.doi.org/10.1016/j.plaphy.2005.07.013 
[22] Ramakrishna, A. and Ravishankar, G.A. (2011) Influence of Abiotic Stress Signals on Secondary Metabolites in Plants. Plant Signaling \& Behavior, 6, 1720-1731. http://dx.doi.org/10.4161/psb.6.11.17613

[23] Jochum, G.M., Mudge, K.W. and Thomas, R.B. (2007) Elevated Temperatures Increase Leaf Senescence and Root Secondary Metabolite Concentration in the Understory Herb Panax quinquefolius (Araliaceae). American Journal of Botany, 94, 819-826. http://dx.doi.org/10.3732/ajb.94.5.819

[24] Wang, S.Y. and Camp, M.J. (2000) Temperatures after Bloom Affect Plant Growth and Fruit Quality of Strawberry. Scientia Horticulturae, 85, 183-199. http://dx.doi.org/10.1016/s0304-4238(99)00143-0

[25] Ikeda, T., Yamazaki, K., Kumakura, H. and Hamamoto, H. (2011) The Effects of High Temperature and Water Stress on Fruit Growth and Anthocyanin Content of Pot-Grown Strawberry (Fragaria×ananassa Duch. cv. "Sachinoka”) Plants. Environment Control in Biology, 49, 209-215. http://dx.doi.org/10.2525/ecb.49.209

[26] Tamura, A. (2004) Effect of Air Temperature on the Content of Sugar and Vitamin C of Spinach and Komatsuna. Horticultural Research (Japan), 3, 187-190. http://dx.doi.org/10.2503/hrj.3.187

[27] Kleinhenz, M.D., French, D.G., Gazula, A. and Scheerens, J.C. (2003) Variety, Shading, and Growth Stage Effects on Pigment Concentrations in Lettuce Grown under Contrasting Temperature Regimens. HortTechnology, 13, 677-683.

[28] Gazula, A., Kleinhenz, M.D., Streeter, J.G. and Miller, A.R. (2005) Temperature and Cultivar Effects on Anthocyanin and Chlorophyll B Concentrations in Three Related Lollo Rosso Lettuce Cultivars. HortScience, 40, 1731-1733.

[29] Christie, P.J., Alfenito, M.R. and Walbot, V. (1994) Impact of Low-Temperature Stress on General Phenylpropanoid and Anthocyanin Pathways: Enhancement of Transcript Abundance and Anthocyanin Pigmentation in Maize Seedlings. Planta, 194, 541-549. http://dx.doi.org/10.1007/BF00714468

[30] Adebooye, O.C., Schmitz-Eiberger, M., Lankes, C. and Noga, G.J. (2010) Inhibitory Effects of Sub-Optimal Root Zone Temperature on Leaf Bioactive Components, Photosystem II (PS II) and Minerals Uptake in Trichosanthes cucumerina L. Cucurbitaceae. Acta Physiologiae Plantarum, 32, 67-73. http://dx.doi.org/10.1007/s11738-009-0379-Z

[31] Yan, Q., Duan, Z., Mao, J., Xun, L. and Fei, D. (2013) Low Root Zone Temperature Limits Nutrient Effects on Cucumber Seedling Growth and Induces Adversity Physiological Response. Journal of Integrative Agriculture, 12, 14501460. http://dx.doi.org/10.1016/S2095-3119(13)60549-3

[32] Malik, S., Andrade, S.A.L., Sawaya, A.C.H.F., Bottcher, A. and Mazzafera, P. (2013) Root-Zone Temperature Alters Alkaloid Synthesis and Accumulation in Catharanthus roseus and Nicotiana tabacum. Industrial Crops and Products, 49, 318-325. http://dx.doi.org/10.1016/j.indcrop.2013.05.009

[33] Sakamoto, M. and Suzuki, T. (2015) Elevated Root-Zone Temperature Modulates Growth and Quality of Hydroponically Grown Carrots. Agricultural Sciences, 6, 749-757. http://dx.doi.org/10.4236/as.2015.68072

[34] Chadirin, Y., Hidaka, K., Takahashi, T., Sago, Y., Wajima, T. and Kitano, M. (2011) Application of Temperature Stress to Roots of Spinach: I. Effect of the Low Temperature Stress on Quality. Environment Control in Biology, 49, 133-139. http://dx.doi.org/10.2525/ecb.49.133

[35] Chadirin, Y., Hidaka, K., Sago, Y., Wajima, T. and Kitano, M. (2011) Application of Temperature Stress to Roots of Spinach: II. Effect of the High Temperature Pre-Treatment on Quality. Environment Control in Biology, 49, 157-164. http://dx.doi.org/10.2525/ecb.49.157

[36] Dalla Costa, L., Tomasi, N. and Gottardi, S. (2011) The Effect of Growth Medium Temperature on Corn Salad [Valerianella locusta (L.) Laterr] Baby Leaf Yield and Quality. HortScience, 46, 1619-1625.

[37] Hanyu, H. and Shoji, K. (2000) Effects of Blue Light and Red Light on Kidney Bean Plants Grown under Combined Radiation from Narrow-Band Light Sources. Environment Control in Biology, 38, 13-24. http://dx.doi.org/10.2525/ecb1963.38.13

[38] Leja, M., Kaminska, I., Kramer, M., Maksylewicz-Kaul, A., Kammerer, D., Carle, R. and Baranski, R. (2013) The Content of Phenolic Compounds and Radical Scavenging Activity Varies with Carrot Origin and Root Color. Plant Foods for Human Nutrition, 68, 163-170. http://dx.doi.org/10.1007/s11130-013-0351-3

[39] Tabata, K., Oba, K., Suzuki, K. and Esaka, M. (2001) Generation and Properties of Ascorbic Acid-Deficient Transgenic Tobacco Cells Expressing Antisense RNA for L-Galactono-1,4-Lactone Dehydrogenase. Plant Journal, 27, 139148. http://dx.doi.org/10.1046/j.1365-313x.2001.01074.x

[40] Dhindsa, R.S., Plumb-Dhindsa, P. and Thorpe, T.A. (1981) Leaf Senescence: Correlated with Increased Levels of Membrane Permeability and Lipid Peroxidation, and Decreased Levels of Superoxide Dismutase and Catalase. Journal of Experimental Botany, 32, 93-101. http://dx.doi.org/10.1093/jxb/32.1.93

[41] Drew, M.C. (1997) Oxygen Deficiency and Root Metabolism: Injury and Acclimation under Hypoxia and Anoxia. Annual Review of Plant Biology, 48, 223-250. http://dx.doi.org/10.1146/annurev.arplant.48.1.223

[42] Parida, A.K. and Das, A.B. (2005) Salt Tolerance and Salinity Effects on Plants: A Review. Ecotoxicology and Environmental Safety, 60, 324-349. http://dx.doi.org/10.1016/j.ecoenv.2004.06.010 
[43] Ribas-Carbo, M., Taylor, N.L., Giles, L., Busquets, S., Finnegan, P.M., Day, D.A., Lambers, H., Medrano, H., Berry, J.A. and Flexas, J. (2005) Effects of Water Stress on Respiration in Soybean Leaves. Plant Physiology, 139, 466-473. http://dx.doi.org/10.1104/pp.105.065565

[44] Neill, S.O. and Gould, K.S. (2003) Anthocyanins in Leaves: Light Attenuators or Antioxidants? Functional Plant Biology, 30, 865-873. http://dx.doi.org/10.1071/FP03118

[45] Zhang, Y.P., Qiao, Y.X., Zhang, Y.L., Zhou, Y.H. and Yu, J.Q. (2008) Effects of Root Temperature on Leaf Gas Exchange and Xylem Sap Abscisic Acid Concentrations in Six Cucurbitaceae Species. Photosynthetica, 46, 356-362. http://dx.doi.org/10.1007/s11099-008-0065-1

[46] He, J., Qin, L. and Lee, S.K. (2013) Root-Zone $\mathrm{CO}_{2}$ and Root-Zone Temperature Effects on Photosynthesis and Nitrogen Metabolism of Aeroponically Grown Lettuce (Lactuca sativa L.) in the Tropics. Photosynthetica, 51, 330-340. http://dx.doi.org/10.1007/s11099-013-0030-5

[47] Bumgarner, N.R., Scheerens, J.C., Mullen, R.W., Bennett, M.A., Ling, P.P. and Kleinhenz, M.D. (2011) Root-Zone Temperature and Nitrogen Affect the Yield and Secondary Metabolite Concentration of Fall- and Spring-Grown, High-Density Leaf Lettuce. Journal of the Science of Food and Agriculture, 92, 116-124. http://dx.doi.org/10.1002/jsfa.4549

[48] Guinn, G. and Hunter, R.E. (1968) Root Temperature and Carbohydrate Status of Young Cotton Plants. Crop Science, 8, 67-70. http://dx.doi.org/10.2135/cropsci1968.0011183X000800010020x

[49] Ntatsia, G., Savvasa, D., Huntenburgc, K., Drueged, U., Hinchae, D.K., Zuthere, E. and Schwarz, D. (2014) A Study on ABA Involvement in the Response of Tomato to Suboptimal Root Temperature Using Reciprocal Grafts with Notabilis, a Null Mutant in the ABA-Biosynthesis Gene LeNCED1. Environmental and Experimental Botany, 97, 11-21. http://dx.doi.org/10.1016/j.envexpbot.2013.09.011

[50] Ryyppo, A., Iivonen, S., Rikala, R., Sutinen, M.L. and Vapaavuori, E. (1998) Responses of Scots Pine Seedlings to Low Root Zone Temperature in Spring. Physiologia Plantarum, 102, 503-512. http://dx.doi.org/10.1034/j.1399-3054.1998.1020404.X

[51] Malcolm, P., Holford, P., McGlasson, B. and Barchia, I. (2008) Leaf Development, Net Assimilation and Leaf Nitrogen Concentrations of Five Prunus Rootstocks in Response to Root Temperature. Scientia Horticulturae, 115, $285-291$. http://dx.doi.org/10.1016/j.scienta.2007.10.010

[52] Lee, S.H., Chung, G.C., Jang, J.Y., Ahn, S.J. and Zwiazek, J.J. (2012) Overexpression of PIP2;5 Aquaporin Alleviates Effects of Low Root Temperature on Cell Hydraulic Conductivity and Growth in Arabidopsis. Plant Physiology, 159, 479-488. http://dx.doi.org/10.1104/pp.112.194506

[53] Neilson, K.A., Scafaro, A.P., Chick, J.M., George, I.S., Van Sluyter, S.C., Gygi, S.P., Atwell, B.J. and Haynes, P.A. (2013) The Influence of Signals from Chilled Roots on the Proteome of Shoot Tissues in Rice Seedlings. Proteomics, 13, 1922-1933. http://dx.doi.org/10.1002/pmic.201200475

[54] Takahashi, S. and Murata, N. (2008) How Do Environmental Stresses Accelerate Photoinhibition? Trend in Plant Science, 13, 178-182. http://dx.doi.org/10.1016/j.tplants.2008.01.005

[55] Allena, D.J. and Orta, D.R. (2001) Impacts of Chilling Temperatures on Photosynthesis in Warm-Climate Plants. Trends in Plant Science, 6, 36-42. http://dx.doi.org/10.1016/S1360-1385(00)01808-2

[56] Blokhina, O., Virolainen, E. and Fagerstedt, K.V. (2003) Antioxidants, Oxidative Damage and Oxygen Deprivation Stress: A Review. Annuals of Botany, 91, 179-194. http://dx.doi.org/10.1093/aob/mcf118

[57] Boo, H.O., Heo, B.G., Gorinstein, S. and Chon, S.U. (2011) Positive Effects of Temperature and Growth Conditions on Enzymatic and Antioxidant Status in Lettuce Plants. Plant Science, 181, 479-484. http://dx.doi.org/10.1016/j.plantsci.2011.07.013

[58] Park, J.S., Kim, J.B., Cho, K.J., Cheon, C.I., Sung, M.K., Choung, M.G. and Roh, K.H. (2008) Arabidopsis R2R3MYB Transcription Factor AtMYB60 Functions as a Transcriptional Repressor of Anthocyanin Biosynthesis in Lettuce (Lactuca sativa). Plant Cell Reports, 27, 985-994. http://dx.doi.org/10.1007/s00299-008-0521-1

[59] Petroni, K. and Tonelli, C. (2011) Recent Advances on the Regulation of Anthocyanin Synthesis in Reproductive Organs. Plant Science, 181, 219-229. http://dx.doi.org/10.1016/j.plantsci.2011.05.009 